\title{
Extramedullary haematopoiesis in the adrenal glands
}

\author{
Mathews Edatharayil Kurian (D) ,' Felix K Jebasingh, ${ }^{1}$ Elanthenral Sigamani, ${ }^{2}$ \\ Nihal Thomas ${ }^{1}$
}

'Department of Endocrinology, Diabetes and Metabolism, Christian Medical College, Vellore, India

${ }^{2}$ Department of Pathology, Christian Medical College, Vellore, India

\section{Correspondence to}

Dr Felix K Jebasingh;

felixjebasingh@msn.com

Accepted 25 August 2020
Check for updates

(c) BMJ Publishing Group Limited 2020. No commercial re-use. See rights and permissions. Published by BMJ.

To cite: Kurian ME, Jebasingh FK, Sigamani E, et al. BMJ Case Rep 2020:13:e238916. doi:10.1136/bcr-2020238916

\section{DESCRIPTION}

Extramedullary haematopoiesis (EMH) is the formation of cellular components of blood, occurring outside of the bone marrow. This is a result of cytokine induction for increased cell production and a greater availability of pluripotent stem cells. While EMH is physiological during fetal development, pathogenic EMH can emanate when physiological haematopoiesis in the bone marrow is ineffective and haematopoietic stem cells migrate to other tissues, as is often seen in disorders of the haematopoietic system, such as thalassemia and myelofibrosis. It has been primarily reported in patients with $\beta$-thalassemia intermedia and haemoglobin E-beta thalassemia. ${ }^{1}$ The spleen and the liver are the most common primary sites for EMH. However, other organs such as lymph nodes, cardiac muscle, mediastinum, lung, breast, kidneys, adrenal glands, thyroid, skin and GIT may also be involved. The diagnosis is almost always histopathological. $\mathrm{EMH}$ in the adrenal glands should be considered as a differential diagnosis in patients with haematological disorders who have adrenal gland masses, in order to prevent any potentially unnecessary or inappropriate therapy. ${ }^{23}$

We report the case of a 36-year-old man who had been known to have $\beta$-thalassemia intermedia and presented to the clinic for the evaluation of recent onset bilateral pedal oedema. Clinical examination revealed no other findings. He had undergone splenectomy in the past, secondary to multiple blood transfusions. He was also known to have hypertension, for which he had been taking antihypertensive

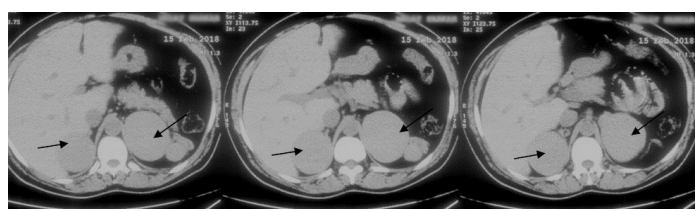

Figure 1 A CT scan of the abdomen showing welldefined, bilateral and non-enhancing adrenal masses approximately $7 \mathrm{~cm}$ in size (indicated with arrows).

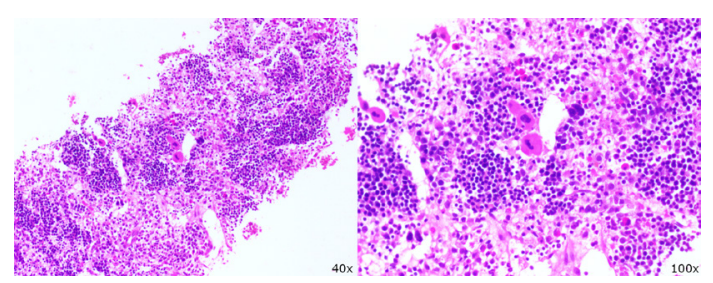

Figure 2 Histopathology showing trilineage haematopoietic elements with mature erythroids, myeloids and megakaryocytes.
Learning points

It is imperative to consider extramedullary haematopoiesis when adrenal enlargement is seen in patients with haematological disorders, such as thalassemia.

- The patient must be adequately evaluated to rule out a functioning adrenal tumour.

- A biopsy and subsequent histopathological evaluation are obligatory for confirming the diagnosis.

medication. Family history was insignificant. The blood picture showed anaemia and other cell lines within normal limits. Ultrasonography of the abdomen revealed bilateral incidental adrenal masses. CT of the abdomen revealed bilateral adrenal masses with an approximate size of $7 \mathrm{~cm}$ (figure 1).

In view of the bilateral adrenal masses, the differential diagnosis considered were tuberculosis, histoplasmosis, lymphoma and the possibility of adrenal extramedullary erythropoiesis. The 08:00 $\mathrm{h}$ serum cortisol was within normal limits and biochemical investigations were not suggestive of a functioning adrenal adenoma. For confirmation of the diagnosis, the patient underwent a CT-guided biopsy of the right adrenal mass. Histopathology was suggestive of EMH, showing fibrocollagenous tissue replaced by haematopoietic elements with mature erythroids, myeloids and megakaryocytes, with no granulomas or adrenal tissue in the biopsied section (figure 2). The patient was reassured and was advised for regular follow-up.

Contributors MEK composed the manuscript. FKJ, ES and NT provided critical review and revised the manuscript.

Funding The authors have not declared a specific grant for this research from any funding agency in the public, commercial or not-for-profit sectors

Competing interests None declared.

Patient consent for publication Obtained.

Provenance and peer review Not commissioned; externally peer reviewed.

ORCID iD

Mathews Edatharayil Kurian http://orcid.org/0000-0003-0822-6760

\section{REFERENCES}

$1 \mathrm{Kim}$ CH. Homeostatic and pathogenic extramedullary hematopoiesis. J Blood Med 2010;1:13-19.

2 Kannan S, Kulkarni P, Lakshmikantha A, et al. Extramedullary haematopoiesis presenting as an adrenal mass. J Clin Diagn Res 2017;11:TJ01 


\section{Images in...}

Copyright 2020 BMJ Publishing Group. All rights reserved. For permission to reuse any of this content visit https://www.bmj.com/company/products-services/rights-and-licensing/permissions/

BMJ Case Report Fellows may re-use this article for personal use and teaching without any further permission.

Become a Fellow of BMJ Case Reports today and you can:

- Submit as many cases as you like

- Enjoy fast sympathetic peer review and rapid publication of accepted articles

- Access all the published articles

- Re-use any of the published material for personal use and teaching without further permission

Customer Service

If you have any further queries about your subscription, please contact our customer services team on +44 (0) 2071111105 or via email at support@bmj.com. Visit casereports.bmj.com for more articles like this and to become a Fellow 